\title{
Meningkatkan Daya Kreatif Siswa Menggunakan Teknologi Digital Sebagai Media Pembelajaran Daring
}

\author{
Endang Kumala Ratih, Setyo Yanuartuti \\ Universitas Negeri Surabaya, Jl. Lidah Wetan, Lidah Wetan, Kec. Lakarsantri, Kota Surabaya, \\ Correspondence Email: endangkumala674@gmail.com, setyoyanuartuti@unesa.ac.id
}

\begin{abstract}
Corona virus affects all aspects of life. The teaching and learning process in the world of education is also affected by the corona virus. Changes in learning from conventional to online make teachers, guardians, and students must be able to adapt to the online learning system. To be able to carry out online learning properly, good cooperation between teachers and guardians is needed so that students are able to work on and absorb school material. the only learning media that can be used in mass for the sake of namely by utilizing technology. There are many mass media that can be used to support the teaching and learning process online, but the most important thing here is that it can be connected to the internet network. Especially in the field of art education, it requires applications that can still increase student creativity amid this pandemic. So that in this study the author aims to convey the management of online learning by using several applications that can be used to support student creativity. This study uses a management approach to analyze data and controls in the implementation of online learning. This research uses descriptive qualitative method, data collection uses participatory observation methods, interviews, literature study, and documentation. Through this research, it can be seen that by using the proper management and utilization of media online learning for art education will continue and can hone children's creativity.
\end{abstract}

\section{Keywords:}

Online learning; creativity; management.

\begin{abstract}
Abstrak
Virus corona mempengaruhi segala aspek kehidupan. Proses belajar mengajar didunia pendidikan juga terkena dampak dari virus corona. Perubahan pembelajaran dari konvensional menjadi online membuat guru, wali murid, dan siswa harus mampu beradaptasi dengan sistem pembelajaran online. Untuk dapat terlaksana pembelajaran online dengan baik maka diperlukan kerjasama yang baik antara guru dan wali murid agar siswa mampu mengerjakan dan menyerap materi sekolah. satu-satunya media pembelajaran yang dapat digunaka dalam massa demi yaitu dengan memanfaatkan teknologi. Banyak media massa yang dapat dimanfaatkan untuk mendukung proses belajar mengajar daring, namun yang paling utama disini dapat terkoneksi dengan jaringan internet. Khususnya dibidang pendidikan seni memerlukan aplikasi yang tetap dapat meningkatkan kreativitas siswa ditengah pandemi ini. Sehingga dalam penelitian ini penulis bertujuan menyampaikan pengelolaan pembelajaran daring dengan menggunakan beberapa aplikasi yang dapat dimanfaatkan untuk mendukung kreativitas siswa. Penelitian ini menggunakan pendekatan manajemen untuk menganalisis data dan pengatur dalam pelaksanaan pembelajarn daring. Penelitian ini menggunakan metode deskriptif kualitatif, pengumpulan data menggunakan metode observasi partisipasi, wawancara, studi pustaka, dan dokumentasi. Melalui penelitian ini bisa dilihat bahwa dengan menggunakan manajemen dan pemanfaatan media yang tepat pembelajaran daring untuk pendidikan seni akan tetap berjalan dan dapat mengasah kreativitas anak.
\end{abstract}

Kata Kunci:

Pembelajaran daring; kreativitas; manajemen

\section{A. PENDAHULUAN}

Indonesia diawal bulan Maret 2020 dilanda wabah pandemi
COVID-19, dalam waktu yang sangat singkat pandemi ini telah mengubah kondisi masyarakat Indonesia. Mulai 
dari budaya lingkungan masyarakat yang mengenakan masker dan cuci tangan setiap hari. Selain itu COVID-19 juga mempengaruhi dalam bidang ekonomi, menurunnya penghasilan dari industri pabrik maka dilakukan keputusan PHK kepada karyawan pabrik. Pendidikan termasuk pada bidang pendidikan khususnya di kota-kota besar yang ada di Surabaya. Karena pandemi ini seluruh proses belajar mengajar dilakukan dari rumah, pandemi yang mengganggu proses belajar mengajar khususnya pada pembelajaran seni budaya yang dominan dengan kegiatan praktek. Pemerintahan dari berbagai kota besar melakukan pembatasan sosial bersekala besar (PSBB) salah satunya yaitu kota Surabaya. Dinas pendidikan kota Surabaya memberlakukan study from home (SFH) bagi seluruh siswa di Surabaya sejak tanggal 20 Maret 2020. Pembelajaran dirubah dengan menggunakan metode daring atau pembelajaran online dan memanfaatkan media sosial sebagai media pembelajaran. Tujuan dari penelitian ini bermaksud memberikan solusi bagi para pendidik seni khususnya untuk anak usia sekolah dalam proses belajar mengajar dengan memanfaatkan tekonologi digital.

Pandemi COVID-19 pada tahun ini sangat mengganggu proses belajar mengajar, pembelajaran yang awalnya dilakukan secara konvensional berubah menjadi pembelejaran daring. Pendidik sebagai fasilitator harus terampil dalam menggunakan media pembelajaran sehingga pembelajaran dapat berpusat pada peserta didik ${ }^{1}$ Selain itu, memanfaatkan tekonologi sebagai media pembelajaran yang mampu memotivasi peserta didik $^{2}$. Daring Kombinasi merupakan model pembelajaran yang memadukan pembelajaran konvensional dengan teknologi informasi yang dituangkan dalam website sehingga peserta didik dapat leluasa mengakses dan mengunduh modul serta dapat memudahkan pendidik memantau keaktifan peserta didik mulai dari keaktifan membuka laman, mengoreksi kuis, dan Ujian Tengah Semester serta Ujian Akhir Semester.

Pendidikan karakter pada anak usia sekolah sangatlah diperlukan untuk membantu mengembangkan bakat pada diri anak. Pendidikan karakter ini bisa dilakukan melalui pembelajaran seni budaya. Pembelajaran ini mengembangkan kemampuan berpikir dan kreatifitas anak. Pembelajaran seni budaya ini juga bisa menjadi wadah bagi remaja untuk mengekspresikan kreasinya. Melalui pembelajaran seni budaya ini pula bisa menjadi pengendali

\footnotetext{
${ }^{1}$ Astra, I Made, dan Rifa Syarifatul Wahidah.

"Peningkatan Keterampilan Proses Sains Peserta Didik Melalui Model Guided Discovery Learning Kelas XI MIPA Pada Materi Suhu dan Kalor". Jurnal Penelitian \& Pengembangan Pendidikan Fisika 3, no. 2 (2017): 181-190.

${ }^{2}$ Sari, Wulan Maya, Riswanto Riswanto, and Partono Partono. "Validitas mobile pocket book berbasis android menggunakan adobe flash pada materi suhu dan kalor." Berkala Ilmiah Pendidikan Fisika 7, no. 1 (2019): 35-42.
} 
remaja untuk tidak melakukan tindak kriminal dengan cara memfokuskan pada kegiatan berkesenian.

Menurut Kuper, kreativitas merupakan sebuah konsep yang majemuk dan multi-dimensial, sehingga sulit didefinisikan secara operasional. Definisi sederhana yang sering digunakan secara luas tentang kreativitas adalah kemampuan untuk menciptakan sesuatu yang baru. Wujudnya adalah tindakan manusia. Melalui proses kreatif yang berlangsung dalam benak orang atau sekelompok orang, produkproduk kreatif tercipta. Produk itu sendiri sangat beragam, mulai dari penemuan mekanis, proses kimia baru, solusi baru atau pernyataan baru mengenai sesuatu masalah dalam matematika danilmu pengetahuan; komposisi musik yang segar, puisi cerita pendek atau novel yang menggugah yang belum pernah ditulis sebelumnya; lukisan dengan sudut pandang yang baru; seni patung atau potografi yang belum ada sebelumnya; sampai dengan terobosan dalam aturan hukum, agama, pandangan filsafat, atau pola perilaku baru3 .

Pembelajaran yang awalnya dilakukan secara konvensional atau bertatap muka disekolah berubah menjadi pembelajaran daring (online) semenjak pandemi COVID19 sudah menjadi sangat gawat, pembelajaran ini tentu memerlukan manajemen untuk mengatur pelaksanaan pembelajaran daring secara efektif dan efisien terutama

${ }^{3}$ Mar'at, Psikologi Perkembangan, 175. dalam bidang pendidikan seni tanpa membatasi proses kratif siswa. Menurut Terry dan Rue ada 5 fungsi utama manajemen, seperti yang diuraikan berikut ini.(1) Planning atau dalam bahasa Indonesia perencanaan, yaitu menentukan tujuan-tujuan yang hendak dicapai pada masa yang akan datang dan apa yang harus diperbuat agar dapat mencapai tuiuan-tujuan itu. (2) Organizing atau dalam Bahasa Indonesia pengorganisasian, adalah mengelompokkan dan menentukan berbagai kegiatan penting dan memberikan kekuasaan untuk melaksanakan kegatan-kegiatan itu. (3) Staffing (penentuan sumber daya manusia) yaitu menentukan keperluan-keperluan sumber daya manusia, pengerahan, penyaringan, latihan, dan pengembangan tenaga kerja. (4) Motivating, yaitu mengarahkan atau menyalurkan perilaku manusia kearah tujuantujuan yang hendak dicapai. (5) Controlling, yang dalam bahasa Indonesia lazim disebut dengan pengawasan, yaitu kegiatan dalam bentuk mengukur pelaksanaan sesuai dengan tujuan-tujuan, menentukan sebab-sebab penyimpangan-penyimpangan dan mengambil tindakan-tindakan korektif yang diperlukan ${ }^{4}$.

Penelitian ini menggunakan pendekatan manajemen sebagai sistem pengelolaan pembelajaran daring yang difokuskan pada pengunaan media digital sebagai media pembelajaran daring. Subjek dalam penelitian ini adalah siswa

\footnotetext{
${ }^{4}$ Takari, Muhammad. Manajemen Seni. 44.
} 
yang melaksanakan pembelajaran daring, beserta orang-orang yang terlibat sebagai informan terdiri dari : guru seni, guru kelas, dan wali murid. Objek penelitian adalah pembelajaran daring dan fenomena yang terjadi dialamnya. Pengumpulan data meliputi : 1) observasi partisipasi, dengan melihat fenomena yang berhubungan langsung maupun tidak langsung dengan subjek dan objek penelitian; 2) wawancara, data didapat dari walimurid dan guru seni; dan 3) studi kepustakaan dan dokumen berupa buku dan foto-foto pembelajaran daring untuk mendapatkan data.

Data hasil penelitian dianalisis dengan cara mengklasifikasikan hingga memberi makna terhadap hasil dari observasi pastisipasi, wawancara, pencatatan, dan perekaman melalui pengumpulan data. Validasi data penelitian dilakukan proses triangulasi untuk kevalidan data, keefektivitasan proses dan hasil yang diinginkan

Pelaksanaan pembelajaran daring yang merupakan model pembelajaran baru bagi siswa dan guru. Dalam melaksanakan pembelajaran daring ini tentu dibutuhkan sebuah perencanaan untuk dapat melaksanakan pembelajaran secara online tanpa mengurangi kreativitas siswa khususnya dibidang pendidikan seni. Penggunaan teknologi digital tentu memiliki keterbatasan dalam proses kreatif siswa, hal tersebut merupakan suatu tantangan tersendiri bagi para pendidik untuk menjadikan teknologi digital sebagai media dalam meningkatkan kreativitas siswa. Pemanfaatan media digital dalam bidang pendidikan seni secara online memerlukan metode, stragtegi, dan teknik khusus untuk tetap dapat meningkatkan kreativitas siswa dimasa meskipun ditengah masa sosial distancing seperti saat ini yang membuat guru memiliki kendala dalam membimbing siswa untuk mengembangkan potensi kreatif siswa dibidang pendidikan seni.

\section{B. HASIL DAN PEMBAHASAN}

Pembelajaran daring yang merupakan proses pembelajaran baru bagi siswa diperlukan strategi, metode, dan teknik khusus supaya siswa bisa belajar dengan nyaman tanpa merasakan beban sehingga materi pelajaran khususnya pada bidang pendidikan seni materi bisa tersampaikan dengan baik dan siswa merasakan senang dan mampu meningkatkan kreativitas siswa dengan memanfaatkan media digital. Untuk bisa mencapai tujuan maka diperlukan manajemen dalam proses pembelajaran.

\section{Planning}

Koontz dan O'Donell dalam bukunya yang bertajuk Principles of Management menjelaskan bahwa perencanaan (planning) adalah fungsi dari manajer dalam rangka pemilihan terhadap berbagai altematif, tujuan, kebijaksanaan, prosedur, dan program dalam manajemen. Selain itu, 
menurut Billy E. Goatz perencanaan adalah pilihan mendasar (fundamental) dan persoalan perencanaan timbul karena terdapat altematifaltematif. Kemudian pakar lainnya Terry mengemukakan tentang perencanaan yaitu pemilihan penghubungan fakta-fakta, serta pembuatan dan penggunaan perkiraanperkiraan, asumsi-asumsi untuk masa yang akan datang, dengan jalan menggambarkan dan merumuskan kegiatankegiatan yang diperlukan untuk mencapai hasil yang diinginkan. Koontz dan O’Donell mengemukakan bahwa prinsip-prinsip perencanaan terdiri dari aspek-aspek berikut ini :(1) proses membantu tercapainya tujuan, (2) prinsip efisiensi pada perencanaan, (3) prinsip mengutamakan perencanaan, (4) prinsip pemerataan perencanaan, (5) prinsip patokan perencanaan, prinsip kebijaksanaan kerja, (7) prinsip waktu, (8) prinsip tata hubungan perencanaan, (9) prinsip altematif, (10) prinsip pembatasa faktor, (11) prinsip keterikatan, (12) prinsip kelenturan, (13) prinsip ketetapan arah, (14) prinsip perencanaan strategis 5 .

\begin{tabular}{cr}
\multicolumn{2}{c}{ Pembelajaran daring } \\
untuk pendidikan seni
\end{tabular}

\footnotetext{
${ }^{5}$ Koontz, Harold dan Cyril O’Donnell. Principles of Management.
}

memerlukan sebuah rencana dengan memanfaatkan waktu dengan yang tepat untuk bisa melaksanakan pembelajaran dengan baik dan meningkatkan kreativitas siswa dengan menggunakan teknologi digital. Selain itu dibutuhkan juga waktu yang fleksibel untuk memberikan kesempatan siswa mengembangkan materi yang didapat sesuai dengan pemahamannya sendiri.

$$
\text { Mengelola waktu }
$$

merupakan kegiatan guru dalam mengatur jam pelajaran. Jam pelajaran daring tidak mesti sama dengan jam pelajaran saat tatap muka. Jam pelajaran tatap muka antara 35-45 menit tergantung masingmasing jenjang pendidikan. Penugasan belajar dalam pembelajaran daring diatur oleh guru yang memungkin melebihi dari jam tatap muka, di sini ada kelonggaran waktu karena mungkin terjadi jaringan onlinennya yang kurang bersahabat, sehingga memerlukan waktu yang lebih dalam pengerjaan tugas ${ }^{6}$.

Waktu pembelajaran daring disesuaikan dengan jam sekolah masing-masing, untuk pembelajaran seni budaya membutuhkan waktu

\footnotetext{
6 Widodo, Hendro, 15 April 2020. "Manajemen Pembelajaran Daring”. Diakses tanggal 14 Mei 2020.

https://radarjogja.jawapos.com/2020/04/15 /manajemen-pembelajaran-daring
} 
6o menit untuk tatap muka sedangkan daring yang bersifat kuis membutuhkan waktu yang agak lama selain pembagian jam dengan mata pelajaran lain, faktor koneksi jaringan yang buruk akibat dari banyaknya pengguna. Dengan sistem waktu yang seperti itu tentu membuat siswa tidak dapat mengembangkan daya kreatif yang dimiliki dengan maksimal, terutama dalam bidang pendidikan seni. Namun, guru dituntut untuk melaksanakan sesuai dengan jadwal tersebut. Waktu yang singkat seperti itu bisa digunakan guru untuk memberikan materi yang sudah diprogramkan dalam rpp. Setelah memberikan materi tersebut siswa diberik jangka waktu setidaknya satu minggu setelah pemberian materi untuk siswa mempelajari dan mengembangkan materi yang sudah diberikan.

\section{Organizing}

Pengaturan waktu untuk siswa diperlukan sebuah pengorganisasian supaya waktu tersebut bisa berjalan dengan efektif dan tidak menganggu mata pelajaran yang lain. Pengorganisasian ini juga bisa mebantu siswa untuk membagi waktu belajar dengan baik. Pengorganisasian (organizing) adalah proses pengelompokkan kegiatankegiatan untuk mencapai tujuan-tujuan dan penugasan setiap kelompok kepada seorang manajer, yang mempunyai kekuasaan, yang perlu untuk mengawasi anggotaanggota kelompok7 .

Prinsip-prinsip

organisasi menurut Koontz adalah mencakup: (a) prinsip kesatuan tujuan, (b) prinsip efisiensi, (c) prinsip rentangan manajemen, (d) prinsip hirarki, (e) prinsip pertanggungjawaban, prinsip keseimbangan antara wewenang dan tanggung jawab, (g) prinsip kesatuan perintah, (h) prinsip tingkatan wewenang, prinsip pembagian kerja, (j) prinsip penetapan tugas, $(\mathrm{k})$ prinsip kelenturan atau penyesuaian, (l) prinsip keseimbangan, (m) prinsip kelangsungan, (n) prinsip kemudahan kepemimpinan ${ }^{8}$.

Pengorganisasian

dalam kelas daring ini dilakukan oleh guru dan wali murid, dibutuhkan kerjasama dan pemahaman satu sama lain tentang tugas dalam pembelajaran daring tersebut. Guru tidak hanya mengordinir siswa tapi juga harus mampu mengordinir wali murid sebagai tangan

\footnotetext{
7 Terry, George R. Dan Leslie W. Rue. DasarDasar Manajemen, 82.

${ }^{8}$ Takari, Muhammad. Manajemen Seni. 44.
} 
kanan guru untuk mampu memfokuskan siswa dalam pelajaran. Kegiatan guru dalam mengatur kegiatan belajar siswa di masingmasing kelas. Guru yang mengajar lebih dari satu kelas untuk satu mata pelajaran, maka melalui media daring, guru membuat forum kelas sejumlah kelasnya dan mata pelajaran yang diampunya, sementara dapat pula bagi guru yang menggunakan WhatsApp group (WAG), anggota kelas dapat dijadikan satu dalam WAG kelasnya untuk satu mata pelajaran ${ }^{9}$.

Guru bisa mengorganisir wali murid dengan cara membuat organisasi dalam sebuah bentuk kelas online yang digunakan untuk memudahkan koordinasi guru kelas dengan wali murid. Guru dapat terus berkomunikasi dan memantau perkembangan siswa dengan menggunakan aplikasi WhatsApp group (WAG), untuk siswa SD dan SMP yang tergabung dalam WhatsApp group (WAG) adalah nomor orang tua karena masih memerlukan pemantauan lebih, sedangkan untuk siswa SMA WhatsApp group (WAG) adalah guru

${ }^{9}$ Widodo, Hendro, 15 April 2020. "Manajemen Pembelajaran Daring". Diakses tanggal 14 Mei 2020.

https://radarjogja.jawapos.com/2020/04/15/manaje men-pembelajaran-daring kelas dan siswanya. Untuk pembelajaran seni budaya biasanya juga ikut dalam group bisa juga materi tersebut disampaikan melalui guru kelas kemudian disampaikan kepada orang tua atau siswa.

\section{Staffing}

Takari mengatakan bahwa penting untuk menggunakan sebuah organisasi yang baik. Namun penting pula untuk menempatkan orang yang tepat yang sesuai dengan bidang pekerjaannya. Kualitas pekerja inilah yang biasanya membuat perbedaan antara keberhasilan dan kegagalan sebuah organisasi ${ }^{10}$.

Organisasi yang telah dibentuk dalam sebuah aplikasi Whatsapp Group tersebut terdiri dari seorang guru kelas dan wali murid dari siswa dan siswi dalam satu kelas sebagai contoh guru kelas IV-A membuat sebuah grou di aplikasi Whatsapp Group yang beranggotakan seluruh wali murid dari siswa kelas IV-A. Guru lain seperti yang mengajarkan pendidikan seni bisa dimasukan juga ke dalam group kelas tersebut, ataupun cukup berkoordinasi dengan guru kelas.

\section{Pengarahan}

Komunikasi yang baik antara guru pendidikan seni,

${ }^{10}$ Takari, Muhammad. Manajemen Seni. 45. 
guru kelas, dan wali murid sangat mempengaruhi keberhasilan dalam pembelajaran daring dalam bidang pendidikan seni. Komunikasi ini bisa terjalin baik dengan adanya sikap yang baim dari masingmasing pihak agar tujuan dari tujuan dari sebuah pembelajaran daring pendidikan seni bisa tercapai. Dari defenisi yang diajukan Terry terlihat bahwa tercapai atau tidaknya tujuan dalam konteks manajemen, tergantung kepada bergerak atau tidaknya seluruh anggota kelompok manajemen, mulai dari tingkat atas, menengah, dan bawah. Segala kegiatan itu terarah kepada sasarannya, hanyalah merupakan pemborosan saja terhadap tenaga kerja, uang, waktu, dan materi. Atau dengan kata lain merupakan pemborosan terhadap perangkat manajemen. Faktor-faktor yang diperlukan untuk penggerakan ini adalah: (1) kepemimpinan, (2) sikap dan moralitas, (3) tatahubungan atau komunikasi, perangsang atau insentif, (5) supervisi, dan (6) disiplin" ${ }^{11}$.

Kegiatan guru dalam mengelola situasi belajar siswa, melalui pembelajaran daring dengan mengerjakan quiz dan soal-soal yang diberikan oleh guru atau pun

${ }^{11}$ Takari, Muhammad. Manajemen Seni. 56. penugasan lainnya. Guru dapat berinterasi,menjelaskan materi secara online melalui aplikasi Zoom, melakukan diskusi, dialog dan tanya jawab. Dalam manajemen pembelajaran ini tentu diminta kepiawaian guru dan kebijaksanaan guru sehingga ritme tugas yang diberikan tidak membebani siswa ${ }^{12}$.

Pelaksanaan pembelajaran dalam pendidikan seni, guru bisa menggunakan materi sebelum masa berlakunya PSBB atau membuat materi baru, yang terpenting dalam satu pertemuan fokus pada satu materi supaya siswa bisa lebih fokus karena memfokuskan siswa dalam pembelajaran daring dengan pembelajaran di sekolah sangat berbeda. Fokus siswa saat pembelajaran dari dirumah tentu tidak semaksimal disekolah karena situasi kondisi yang sangat berbeda, disinilah peran orang tua untuk selalu mendampingi dan membuat siswa tetap fokus dalam pembelajaran daring. Pembelajaran daring untuk pendidikan seni untuk penyampaian materi bisa menggunakan aplikasi zoom dengan cara pertemuan tatap muka antara guru dengan siswa secara virtual. Materi bicaan juga bisa dilberikan kepada siswa dengan menggunakan aplikasi Sway yang merupakan salah satu dari aplikasi yang termuat dalam Microsoft 365 yang

\footnotetext{
12 Widodo, Hendro, 15 April 2020. "Manajemen Pembelajaran Daring". Diakses tanggal 14 Mei 2020.

https://radarjogja.jawapos.com/2020/04/15/manaje men-pembelajaran-daring
} 
disediakan

pemerintah.

Pembelajaran seni tidak cukup hanya pemberian materi saja, untuk mengembangkan kreativitas siswa diperlukan juga pembelajaran praktek. Media digital yang bisa digunakan untuk meningkatkan kreativitas siswa bisa menggunakan aplikasi yang mudah diakses dengan menggunakan android. Seperti dalam bidang seni lukis guru bisa mengarahkan siswa untuk mengakses aplikasi SketchBook, Sketc-Draw \& Paint, Paper Draw, Medi Bang Paint dsb untuk melatih kemampuan siswa dalam menggambar dan mengembangkan daya kreatif menggunakan fiturfitur yang sudah disediakan dalam aplikasi tersebut.

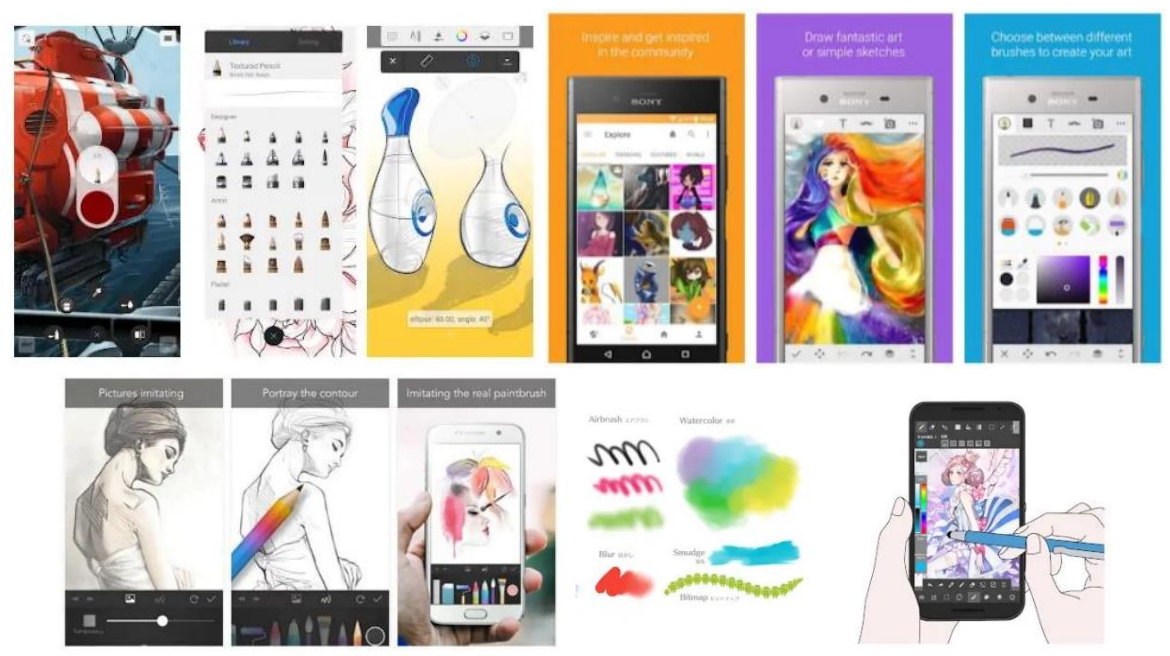

Gambar 1 : Aplikasi SketchBook, Sketc-Draw \& Paint, Paper Draw, Medi Bang Paint yang dapat dimanfaatkan untuk menggambar (Dok. Penulis 2020).

Bidang seni pertunjukan seperti seni tari, seni musik, dan teater juga bisa memanfaatkan media digital untuk mengasah kemampuan siswa dibidangnya masing-masing. Bidang seni tari, guru bisa mengarahkan siswanya untuk membuat video tari dengan menggunakan materi yang sudah diberikan dalam pembuatan video tersebut siswa secara tidak langsung dituntut untuk benar-benar menguasai materi tari dan melatih kepekaan siswa terhadap musik, karena dalam pembuatan video tersebut siswa menari secara individu dan tidak ada teman yang bisa dicontoh seperti ketika belajar tari di sekolah. Penggunaan aplikasi youtube, zoom, tiktok, dsb bisa membantu dalam proses pembelajaran daring seni tari.

Guru menggunakan metode pembelajaran daring dengan menggunakan media youtube dan tugas lainnya. Materi yang digunakan dalam masa study from home ini merupakan lanjutan dari materi sebelum masa PSBB. Guru memberikan contoh 
materi dengan cara mengirim video di youtube, dalam video materi yang disampaikan tersebut guru mempraktekan pada siswa.

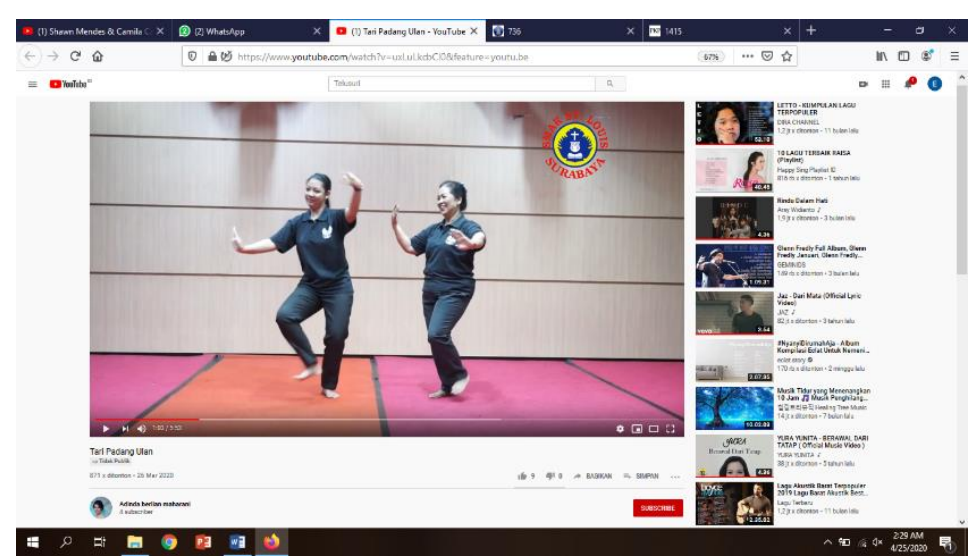

Gambar 2 : Guru memberikan contoh tari (Dok Penulis : 2020)

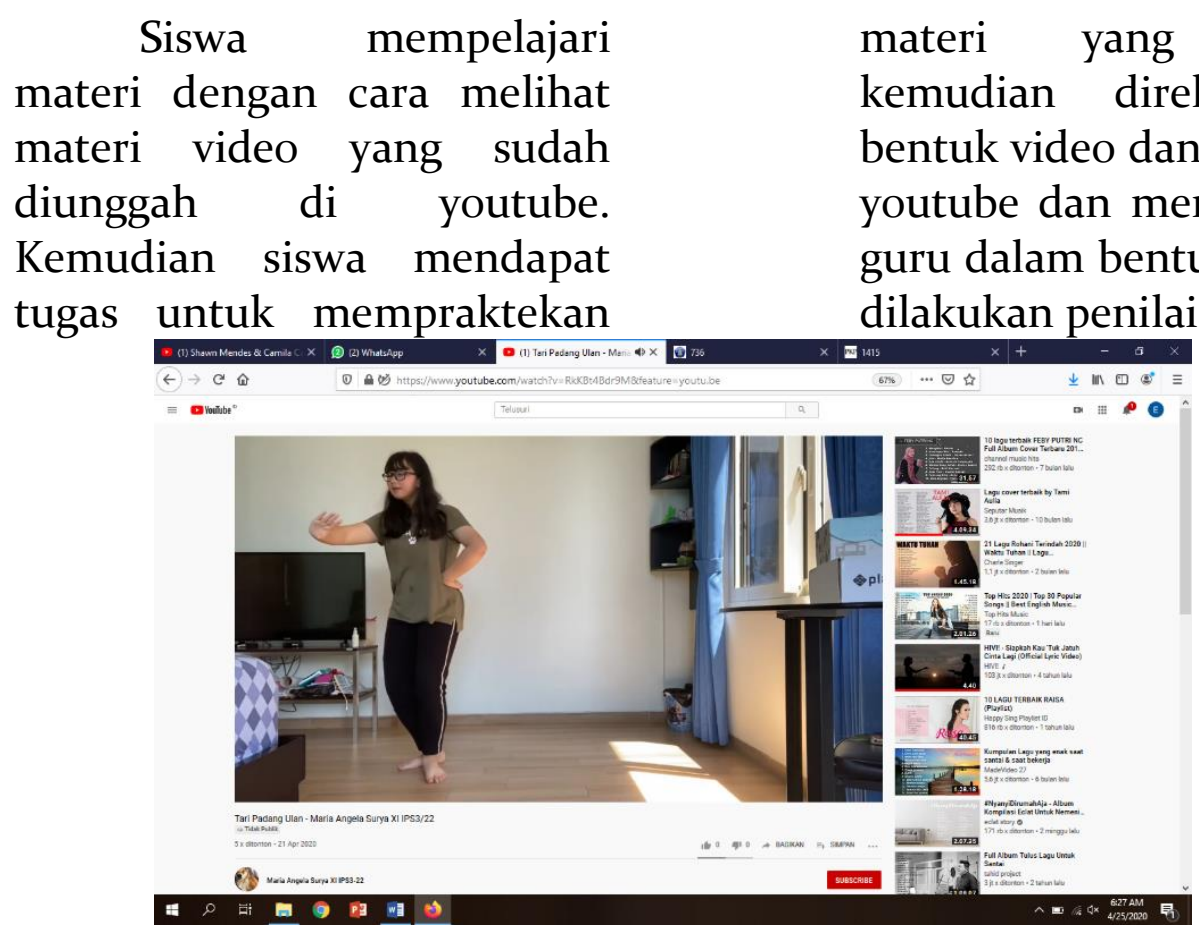

Gambar 3 : Siswa sedang mempraktekan materi tari padang ulan yang diunggah di youtube sebagai tugas sekolah (Dok. Penulis 2020)

Selain menggunakan aplikasi youtube guru bisa mengarahkan siswa saat berproses dengan menggunakan aplikasi zoom dengan menggunakan zoom siswa bisa melakukan kolaborasi video tari atau musik. Dalam penggabungan video tari atau musik ini bisa menggunakan aplikasi kine master, dsb untuk menghasilkan kolaborasi video tari atau musik. 


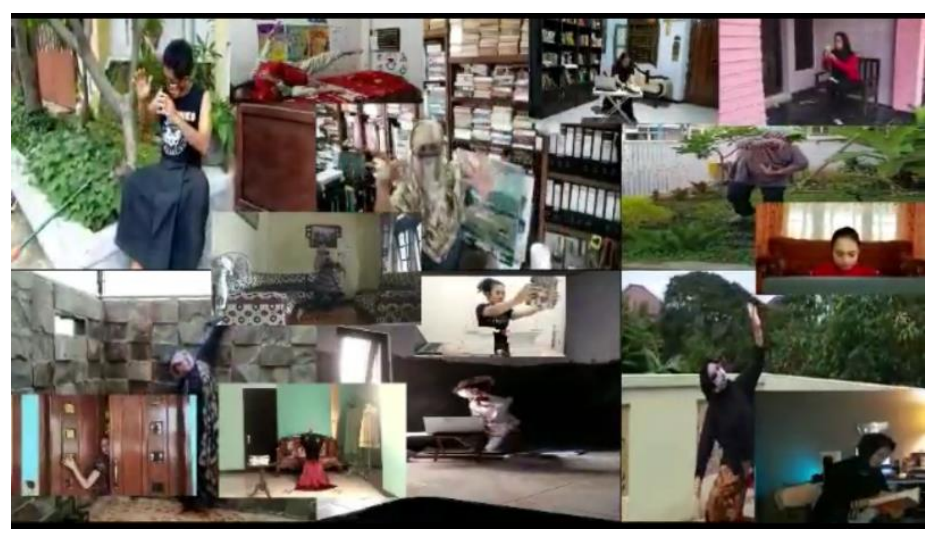

Gambar 4 : Kolaborasi Tari (Dok. Penulis 2020)

Proses pengerjaan tugas

oleh siswa tentu akan didampingi oleh wali murid sehingga wali murid juga bisa mengetahui perkembangan siswa dalam bidang seni. Dalam pengerjaan tugas tersebut diberikan waktu sedikit lebih lama dari pada biasanya bisa sekitar 1 - 2 minggu dari pemberian tugas tersebut.

\section{Controling}

\begin{tabular}{|c|c|}
\hline \multicolumn{2}{|l|}{ Proses } \\
\hline materi & dilakukan \\
\hline kemudian & di \\
\hline gc & \\
\hline
\end{tabular}
pekerjaan yang dilakukan siswa. Pengawasan adalah mengecek atau mengatur seperti pembayaran, menyesuaikan dengan batasbatas seperti kecepatan, serta menguji atau memeriksa dengan bukti atau pengalaman yang sama atau sebaliknya. Maksud dan tujuan pengawasan dalam sistem manajemen adalah sebagai berikut. (1) Untuk mengetahui jalannya pekerjaan apakah lancar atau tidak. (2) Untuk memperbaiki kesalahan kesalahan yang dibuat oleh pegawai dan mengusahakan pencegahan agar tidak terulang kembali kesalahan yang sama atau timbulnya kesalahankesalahan yang baru. (3) Untuk mengetahui apakah penggunaan anggaran yang telah ditetapkan dalam perencanaan terarah kepada sasarannya dan sesuai dengan yang telah ditentukan. (4) Untuk mengetahui apakah pelaksanaan biaya sesuai dengan program, fase, tingkat pelaksanaan seperti yang telah ditentukan dalam perencanaan atau tidak. (5) Untuk mengetahui hasilpekerjaan dengan dibandingkan kepada yang telah ditetapkan dalam rencana (standar), dan sebagai tambahan. (6) Untuk mengetahui apakah pelaksanaan kerja sesuai dengan prosedur dan 
kebijakan yang telah ditentukan ${ }^{13}$.

Pengawasan dalam proses pembelajaran daring adalah pengawasan terhadap proses penyerapan siswa tentang materi yang diberikan dan seberapa kreatif siswa dalam pemanfaatan media digital untuk mengerjakan tugas yang diberikan. Proses tersebut dilakukan siswa secara mandiri berdasarkan materi yang mereka tangkap. Proses latihan siswa bisa dipantau berdasarkan hasil dari laporan wali murid kepada guru berupa foto latihan dan foto mengerjakan tugas. Bisa juga dilakukan beberapa kali pertemuan virtual untuk sesi konsultasi dengan guru, kemudian guru mengarahkan siswa untuk memperbaiki tugasnya.

Setelah siswa mengumpulkan tugas kemudian di evaluasi oleh guru dan hasil evaluasi tersebut disampaikan kepada siswa sehingga siswa dapat memahami kekurangan yang harus diperbaiki dan kelebihan yang harus ditingkatkan atau ditonjolkan dalam karya atau tugas tersebut. Setelah siswa memahami hasil evaluasi siswa diberikan kesempatan untuk menentukan tema dan membuat karya sesuai dengan keinginan mereka, disinilah siswa bisa memahami sebuah proses dalam membuat sebuah karya.

${ }^{13}$ Takari, Muhammad. Manajemen Seni. 59-60.

\section{SIMPULAN}

Pembelajaran daring yang sekarang telah dilaksanakan oleh guru dan siswa akibat adanya wabah COVID-19 membuat guru bidang pendidikan seni memutar akal untuk bisa menyampaikan materi dengan baik dan mampu mengembangkan kreativitas siswa dengan memanfaatkan media digital. Pembelajaran daring dengan menggunakan pendekatan manajemen yang berfungsi sebagai pengatur waktu pembelajaran, mengorganisir orang yang terlibat dalam kelas, dan proses pembelajaran agar tujuan dari pembelajaran tersebut dapat tersampaikan sesuai dengan standart materi yang diberikan. Dengan tercapainya tujuan tersebut siswa dapat mengembangangkan kreativitas mereka dengan baik. Selain itu penentuan media digital yang tepat dan dapat diakses dengan mudah sangat mendukung kreativitas siswa.

Pelaksanaan pembelajaran daring guru bisa melakukan pembelajaran secara virtual dengan menggunakan aplikasi yang bisa bertatap muka, sehingga guru bisa mengarahkan muridnya untuk mendalami teknik pada meteri tersebut. Dengan begitu siswa tetap bisa meningkatkan kualitas teknik, hafalan, dan pemahaman meskipun mereka menjalani study from home. Guru juga bisa membuat sebuah power point yang berisikan tentang foto dan penjabaran dari setiap teknik gerak dalam tari tersebut untuk dipelajari siswa yang kemudian 
dipraktekan siswa dan dilakukan sebuah evaluasi. Pemberian waktu pengerjaan tugas dan diberikan kebebasan siswa dalam menentukan membuat karya dengan menggunakan media digital yang dikuasai dengan memenuhi beberapa persyaratan seperti penentuan tema dari guru kemudian dikembangkan siswa tersebut juga mampu meningkatkan kreativitas siswa meskipun sedang melaksanakan pembelajaran online.

\section{DAFTAR PUSTAKA}

Afiif, Ahmad, and Ridwan Idris. "Pengaruh implementasi manajemen kelas terhadap perilaku belajar mahasiswa pada jurusan manajemen pendidikan islam fakultas tarbiyah dan keguruan UIN ALAUDDIN makassar." Lentera Pendidikan: Jurnal Ilmu Tarbiyah dan Keguruan 19, no. 2 (2017): 131-145. Agustin, Farida, Fitra Putri Oganda, Ninda Lutfiani, and Eka Purnama Harahap. "Manajemen Pembelajaran Daring Menggunakan Education Smart Courses." Technomedia Journal 5, no. 1 (2020): 40-53.

Astra, I. Made, and Rifa Syarifatul Wahidah. "Peningkatan keterampilan proses sains siswa melalui model guided discovery learning kelas XI MIPA pada materi suhu dan kalor." Jurnal Penelitian \& Pengembangan Pendidikan Fisika 3, no. 2 (2017): 181-190.

Bilfaqih, Y., \& Qomarudin, M. N. Esensi

Penyusunan

Materi

Pembelajaran

Daring.

Deepublish, 2015 .
Destiani, A., Saparahayuningsih, S. and Wembrayarli, W., 2016. Upaya peningkatan kreativitas seni rupa siswa melalui teknik pencetakan dengan bantuan Media Asli. Jurnal Ilmiah Potensia, 1(1), pp.7-14.

Helsa, Helsa, and Agustina Hendriati. "Kemampuan Manajemen Kelas Guru: Penelitian Tindakan Di Sekolah Dasar Dengan SES Rendah." Jurnal Psikologi 16, no. 2 (2017): 89.

Istanto, Riza. "Pendekatan Tematik Dalam Pembelajaran Seni Grafis Cetak Tinggi Bahan Alam: Upaya Peningkatan Kreativitas Siswa Sekolah Dasar." Imajinasi: Jurnal Seni 9, no. 2 (2015): 143-152.

Iqbal, Muhammad, Sri Latifah, and Irwandani Irwandani. "Pengembangan Video Blog (Vlog) Channel Youtube Dengan Pendekatan Stem Sebagai Media Alternatif Pembelajaran Daring." Inovasi Pembangunan: Jurnal Kelitbangan 7, no. 2 (2019): 135135 .

Kuntarto, Eko. "Keefektifan Model Pembelajaran Daring dalam Perkuliahan Bahasa Indonesia di Perguruan Tinggi." Indonesian Language Education and Literature 3, no. 1 (2017): 99-110.

Koontz, Harold dan Cryl O'Donnel. Principles of Management. New York: McGraw-Hill Book Company, 1959.

Mar'at, Samsunuwiyati. Psikologi Perkembangan. Bandung: PT Remaja Rosdakarya, 2006.

Nugraha, Muldiyana. "Manajemen Kelas dalam Meningkatkan Proses Pembelajaran." Tarbawi: Jurnal Keilmuan Manajemen Pendidikan 4, no. o1 (2018): 2744 . 
Rimbarizki, Rimbun. "Penerapan Pembelajaran Daring Kombinasi Dalam Meningkatkan Motivasi Belajar Peserta Didik Paket C Vokasi di Pusat Kegiatan Belajar Masyarakat (PKBM) Pioneer Karanganyar." J+ PLUS UNESA 6, no. 2 (2017).

Sari, Wulan Maya, Riswanto Riswanto, and Partono Partono. "Validitas mobile pocket book berbasis android menggunakan adobe flash pada materi suhu dan kalor." Berkala Ilmiah Pendidikan Fisika 7, no. 1 (2019): 35-42.

Sukama. Dasar-Dasar Manajemen. Bandung: Mandar Maju, 1992.
Takari, Muhammad. Manajemen Seni. Sumatera Utara : Studi Kultura, fakultas Sastra, Universitas Sumatera Utara, 2008.

Terry, George R. Dan Leslie W. Rue. Dasar-Dasar Manajemen (alihbahasa G.A. Ticolu). Jakarta: Bumi Aksara, 2000.

\section{Internet}

Widodo, Hendro, 15 April 2020. "Manajemen Pembelajaran Daring”. Diakses tanggal 14 Mei 2020.

https://radarjogja.jawapos.com/ 2020/04/15/manajemenpembelajaran-daring/ 